\title{
Immunohistochemical analysis of oxidative stress and DNA repair proteins in normal mammary and breast cancer tissues
}

\author{
Carol D Curtis, Daniel L Thorngren, Ann M Nardulli*
}

\begin{abstract}
Background: During the course of normal cellular metabolism, oxygen is consumed and reactive oxygen species (ROS) are produced. If not effectively dissipated, ROS can accumulate and damage resident proteins, lipids, and DNA. Enzymes involved in redox regulation and DNA repair dissipate ROS and repair the resulting damage in order to preserve a functional cellular environment. Because increased ROS accumulation and/or unrepaired DNA damage can lead to initiation and progression of cancer and we had identified a number of oxidative stress and DNA repair proteins that influence estrogen responsiveness of MCF-7 breast cancer cells, it seemed possible that these proteins might be differentially expressed in normal mammary tissue, benign hyperplasia $(\mathrm{BH})$, ductal carcinoma in situ (DCIS) and invasive breast cancer (IBC).

Methods: Immunohistochemistry was used to examine the expression of a number of oxidative stress proteins, DNA repair proteins, and damage markers in 60 human mammary tissues which were classified as BH, DCIS or IBC. The relative mean intensity was determined for each tissue section and ANOVA was used to detect statistical differences in the relative expression of $\mathrm{BH}, \mathrm{DCIS}$ and IBC compared to normal mammary tissue.

Results: We found that a number of these proteins were overexpressed and that the cellular localization was altered in human breast cancer tissue.

Conclusions: Our studies suggest that oxidative stress and DNA repair proteins not only protect normal cells from the damaging effects of ROS, but may also promote survival of mammary tumor cells.
\end{abstract}

\section{Background}

The multistep model of human breast cancer progression suggests that invasive breast cancer (IBC) develops in a stepwise manner from premalignant hyperplasia to ductal carcinoma in situ (DCIS) to metastatic carcinoma [1]. Benign hyperplasia (BH), which involves the proliferation of epithelial cells, commonly develops with aging and may increase the risk of breast cancer [2]. DCIS, the most common non-invasive form of breast cancer, is an abnormal proliferation of epithelial cells confined to the ducts. However, 1-2\% of DCIS patients progress to IBC as cells begin to invade the basement membrane. Once the basement membrane has been breached, cells can migrate from the primary tumor through the blood

\footnotetext{
* Correspondence: anardull@life.uiuc.edu

* Correspondence: anardull@life.uiuc.edu Urbana IL 61801, USA
}

(c) 2010 Curtis et al; licensee BioMed Central Ltd. This is an Open Access article distributed under the terms of the Creative Commons Attribution License (http://creativecommons.org/licenses/by/2.0), which permits unrestricted use, distribution, and reproduction in any medium, provided the original work is properly cited.

stream to secondary sites where the cells colonize. Metastatic cancer is the leading cause of cancer-related morbidity and mortality $[3,4]$.

It has been suggested that aging results from exposure of cellular macromolecules to reactive oxygen species (ROS) and that accumulation of ROS-induced damage is responsible for the development of diseases associated with aging, including cancer [5-9]. Oxidative stress response proteins are needed to prevent the accumulation of ROS, which include superoxide, hydrogen peroxide and hydroxy radical. $\mathrm{Cu} / \mathrm{Zn}$ superoxide dismutase (SOD1) helps to regulate ROS levels by converting superoxide to hydrogen peroxide, which can then be converted to $\mathrm{H}_{2} \mathrm{O}$ (Fig. 1, Ref [10]). If not effectively dissipated, intracellular ROS accumulation can result in nitration and/or oxidation of cellular proteins including numerous transcription factors [11-13]. Other proteins involved in redox regulation including thioredoxin 
(Trx), thioredoxin reductase (TrxR) and apurinic/apyrimidinic endonuclease 1/redox factor-1 (Ape1/Ref-1) are important in reducing oxidized cellular proteins and play critical roles in maintaining transcription factor activity [12-14]. Similarly, protein disulfide isomerase (PDI) acts as a molecular chaperone to maintain the structural integrity of numerous proteins including estrogen receptor $\alpha$ (ER $\alpha$, Refs $[13,15])$. We have shown that together, these oxidative stress proteins form an interactive network and that they act collectively to regulate oxidative stress and maintain a functional cellular environment [15-18].

Oxidative stress can produce DNA lesions such as 8-oxoguanine (8-OxoG), which are recognized and removed by cellular DNA glycosylases leaving abasic sites. Likewise, alkylating agents can convert guanine residues to 3-methylguanines, which are removed by the DNA repair protein 3-methyladenine DNA glycosylase (MPG) to produce abasic sites. The abasic sites are recognized by Ape $1 / \operatorname{Ref}-1$, which cleaves the adjacent DNA backbone to continue the DNA repair process $[19,20]$. However, if abasic sites accumulate, doublestranded DNA breaks can occur [21]. The histone $\mathrm{H} 2 \mathrm{AX}$ is rapidly phosphorylated when double-stranded breaks are formed and subsequently acts to recruit DNA repair proteins $[22,23]$. If damaged DNA is not repaired, genomic integrity can be compromised and unrestrained proliferation of aberrant cells may occur $[9,24]$.

Our laboratory identified oxidative stress (SOD1, Ape1/Ref-1, Trx, TrxR and PDI) and DNA repair

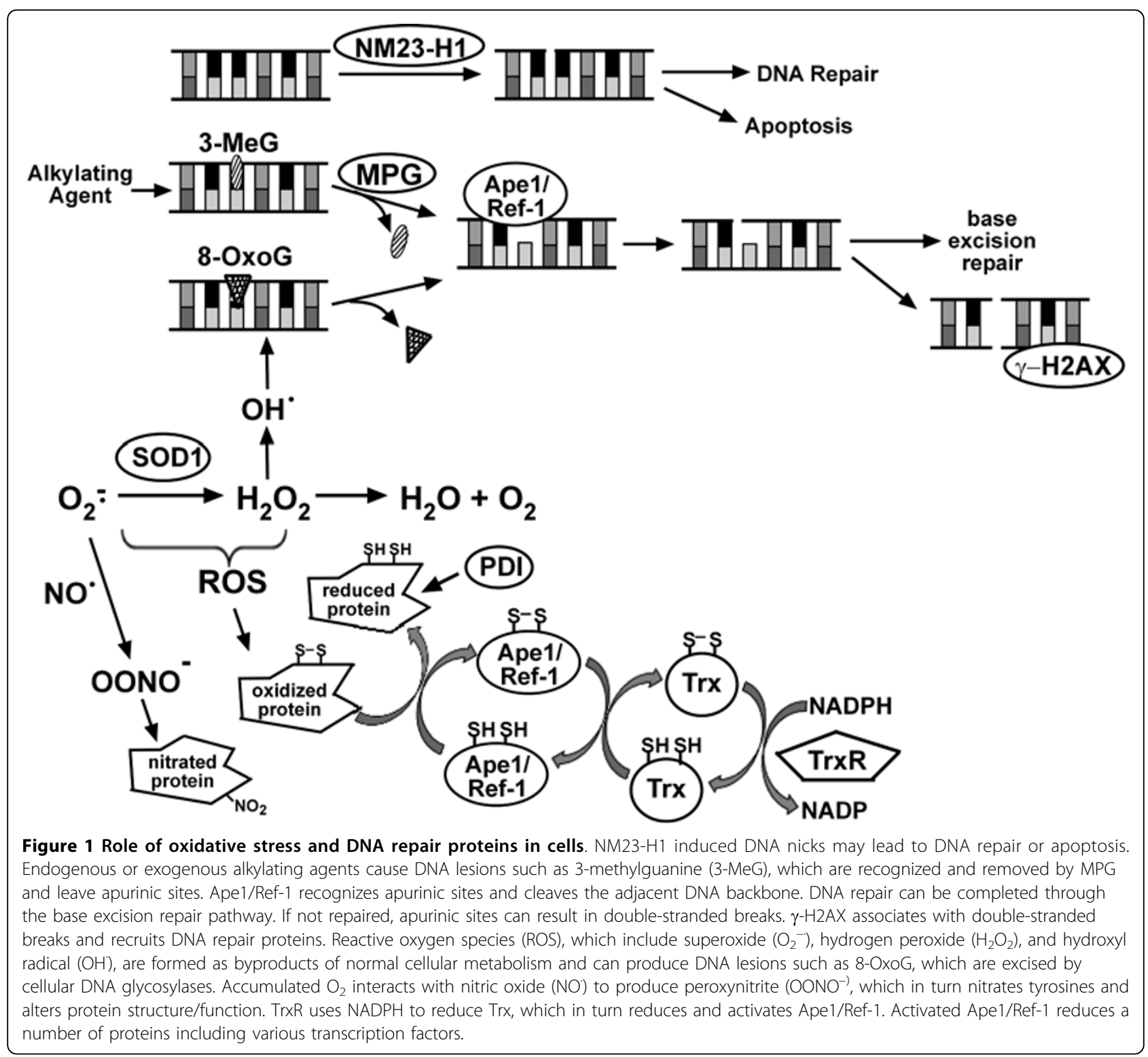


(NM23-H1, MPG and Ape1/Ref-1) proteins associated with the DNA-bound ER $\alpha[15-18,25,26]$ and showed that each of these proteins influences estrogen-responsive gene expression in MCF-7 human breast cancer cells. Because it seemed possible that dysregulation of any one of these proteins might result in increased ROS accumulation and/or unrepaired DNA damage and could feasibly promote oncogenesis, we examined their expression as well as the damage markers 8-OxoG, $\gamma-\mathrm{H} 2 \mathrm{AX}$ and nitrotyrosine, in normal mammary tissue, $\mathrm{BH}, \mathrm{DCIS}$ and IBC.

\section{Methods}

Tissue

Ten serial sections of 60 mammary tissues, which were classified by a board certified pathologist as BH, DCIS or IBC, were obtained from Carle Foundation Hospital (Urbana, IL). These tissues were procured from biopsies performed and archived in 2007 from female patients ranging in age from 26 to 88 years old. Patient characteristics are summarized in Table 1. Normal mammary tissues were obtained from 37 and 81 year old females and had very similar protein localization and expression patterns. This study was approved by the Institutional Review Boards of the University of Illinois at UrbanaChampaign (06171) and Carle Foundation Hospital (05-44). The identity of all patients is the sole property of Carle Foundation Hospital and has not been nor will it in the future be shared with the investigators.

\section{Immunohistochemistry}

Paraffin-embedded blocks were sectioned and mounted on frost-free slides. The 3-10 $\mu \mathrm{m}$ sections were deparaffinized in xylene and rehydrated through a series of graded alcohols. Slides were washed with $1 \times$ PBS and endogenous peroxidases were blocked with $1.5 \%$ hydrogen peroxide in $1 \times \mathrm{PBS}$ for $20 \mathrm{~min}$ at $25^{\circ} \mathrm{C}$. After three 5 min washes in $1 \times$ PBS, slides were incubated in blocking solution $(1 \times$ PBS with $0.1 \%$ Triton $\mathrm{X}-100,3 \%$ bovine serum albumin) with $5 \%$ normal donkey serum for 10 min at $25^{\circ} \mathrm{C}$. Control (no primary antibody) and experimental slides were incubated overnight at $4^{\circ} \mathrm{C}$, respectively, in blocking solution alone or blocking solution

\section{Table 1 Patient characteristics}

\begin{tabular}{lcc}
\hline Clinicopathologic Data & Number & Percentage (\%) \\
\hline Patient Age & 14 & 23.3 \\
$<40$ years old & 24 & 40.0 \\
$40-60$ years old & 22 & 36.7 \\
$>60$ years old & & \\
Histologic classification & 16 & 26.7 \\
Benign Hyperplasia & 17 & 28.3 \\
Ductal Carcinoma In Situ & 27 & 45.0 \\
Invasive Breast Cancer & & \\
\hline
\end{tabular}

with SOD1 (1:400, sc-11407; Santa Cruz Biotechnology, Santa Cruz CA), Ape1/Ref-1 (1:400, sc-17774; Santa Cruz Biotechnology, Santa Cruz CA), PDI (1:200, sc30932; Santa Cruz Biotechnology, Santa Cruz CA), Trx (1:400, ab16835; Abcam, Cambridge MA), TrxR (1:400, ab16840; Abcam, Cambridge MA), NM23-H1 (1:400, sc343; Santa Cruz Biotechnology, Santa Cruz CA), MPG (1:600, ab55461; Abcam, Cambridge MA), 8-oxoguanine (1:400, ab64548; Abcam, Cambridge MA), $\gamma$-H2AX (1:1000, ab2893; Abcam, Cambridge MA), or nitrotyrosine (1:800, 06-284; Millipore, Billerica MA) antibody. Biotin-conjugated secondary antibody (1:200; Jackson ImmunoResearch, West Grove PA) was added and slides were incubated at $25^{\circ} \mathrm{C}$ for $30 \mathrm{~min}$ and then washed three times with $1 \times$ PBS. The ABC Peroxidase Staining kit (1:100 dilution of each Reagent $A$ and $B$ in $1 \times$ PBS, 32020; Thermo Scientific, Rockford IL) was applied at $25^{\circ} \mathrm{C}$ for $30 \mathrm{~min}$. After 3 washes with $1 \times$ PBS, staining was visualized with peroxidase-sensitive Sigmafast 3,3' Diaminobenzidine tablets (DAB; Sigma, St. Louis MO). Exposure times were synchronized so that all tissues samples within an antibody group were exposed to DAB for the exact same time. All slides were counterstained with $0.1 \%$ methyl green (Sigma, St. Louis MO) for 3 min at $60^{\circ} \mathrm{C}$, dehydrated in ethanol, cleared in xylene and mounted with Permount (Fisher Scientific, Pittsburgh PA). Images were obtained at $40 \times$ using a Leica DMI4000B confocal microscope with the Retiga 2000R digital camera. Exposure times were kept constant for all samples.

\section{Data Analysis}

For each antibody, at least five sections of normal mammary tissue were stained in parallel with $\mathrm{BH}, \mathrm{DCIS}$ and IBC sections. Approximately 20 images from 5-6 normal mammary sections (2-3 sections from each normal patient) and 6-8 images for each $\mathrm{BH}$, DCIS or IBC section were collected for a total of $\sim 4500$ images. All images were analyzed using Image Pro Plus software (Media Cybernetics, Bethesda MD). The total intensity of staining and the area covered by whitespace (non-tissue) was recorded for each image (6-8 images/slide). A script was written to analyze multiple images consecutively and all data was exported to Excel (Microsoft, Redmond WA) for analysis. To determine the area covered by tissue in each image, whitespace (non-tissue) area was subtracted from the total area of the image. The intensity per area was determined by dividing the total staining intensity by the tissue area calculated for each image and averaging the 6-8 images taken for each tissue sample. To determine relative intensity per area, the mean intensity per area determined for each tissue sample was compared to the mean intensity per area of the normal tissue samples. Cellular localization (cytoplasm, nucleus or both) and tissue distribution (stroma, 
epithelium or both) were determined by visual inspection of 6-8 fields per sample.

\section{Results}

Normal mammary tissue was used initially to optimize conditions for detection of the oxidative stress and DNA repair proteins. However, because the expression of the damage markers was undetectable in normal mammary tissue, IBC sections were utilized. To ensure that the expression patterns observed were due to the specificity of the primary antibody and were not produced by non-specific secondary antibody binding, immunohistochemistry (IHC) was performed without primary antibody or with antibodies which had been preabsorbed using purified protein or peptide containing an antibody-specific epitope (Fig. 2 and data not shown). No background staining was produced with the rabbit, mouse or goat secondary antibodies used in the experiments described herein.

The expression of the oxidative stress proteins (SOD1, Ape1/Ref-1, Trx, TrxR, and PDI), the DNA repair proteins (Ape1/Ref-1, NM23-H1 and MPG), and the damage markers (8-OxoG, $\gamma-\mathrm{H} 2 \mathrm{AX}$ and nitrotyrosine) were examined in 60 mammary tissues that were classified as BH, DCIS or IBC. The characteristics of the 26 to 88 year old female patients from whom the tissues were obtained are summarized in Table 1.

\section{Oxidative stress proteins}

In normal human mammary tissue, SOD1 was primarily localized in the nucleus and was present in both epithelial and stromal cells (Fig. 3A). Although there was no significant change in SOD1 expression in $\mathrm{BH}$ compared to normal mammary tissue, quantitative analysis of staining intensity indicated that $69 \%(11 / 15)$ of DCIS and $72 \%(18 / 25)$ of IBC tissues examined had higher SOD1 expression than normal mammary tissue (Fig. 3A and $3 \mathrm{~B})$.

Ape1/Ref-1 expression was increased in 92\% (12/13) of DCIS and $86 \%(19 / 22)$ of IBC tissues compared to normal mammary tissue (Fig. 4A and 4B). Although Ape1/Ref-1 was mainly restricted to the epithelial cell nuclei in normal tissue and $\mathrm{BH}$, it was present in the cytoplasm and nuclei of DCIS and IBC tissues (Fig. 4C). Thus, there was a redistribution of Ape1/Ref- 1 from the nuclear to the cytoplasmic compartment in the malignant breast cancer cells.

Although Trx expression was similar in normal mammary tissue and BH (Fig. 5), 80\% (12/15) of DCIS and $95 \%(21 / 22)$ of IBC tissues had greater than normal expression (Fig. 5A and 5B) indicating that Trx was overexpressed in mammary tumors. Analysis of Trx expression in normal tissue indicated that it was principally localized in epithelial nuclei, but was also present in the cytoplasm in BH, DCIS and IBC (Fig. 5C).

TrxR was primarily localized in the nuclei of stromal and epithelial cells in normal breast tissue but was not highly expressed (Fig. 6A). No changes in TrxR expression were observed in $\mathrm{BH}, \mathrm{DCIS}$ or IBC compared to normal breast tissue (Fig. 6A and 6B).

PDI expression was increased in $81 \%(13 / 16)$ of $\mathrm{BH}$, $86 \%(13 / 15)$ of DCIS and $86 \%(19 / 22)$ of IBC tissues compared to normal breast tissue (Fig. 7A and 7B). Interestingly, PDI expression was increased more dramatically in ER $\alpha$-positive than ER $\alpha$-negative IBC (Fig. 7C). In normal mammary tissue, PDI expression was primarily restricted to the myoepithelial cells and, while most (14/16) BH tissues maintained this myoepithelial tissue distribution, this distinctive staining pattern was lost in DCIS (9/15) and IBC (20/22) (data not shown). Furthermore, while PDI expression was observed in both the nucleus and cytoplasm in normal tissue, there was a complete loss of nuclear PDI expression in IBC (Fig. 7D).

\section{DNA repair proteins and damage markers}

NM23-H1 was highly expressed in the nuclei and cytoplasm of epithelial and stromal cells in normal mammary tissue (Fig. 8A). Although 92\% (23/25) of IBC tissues had greater than normal NM23-H1 staining (Fig.
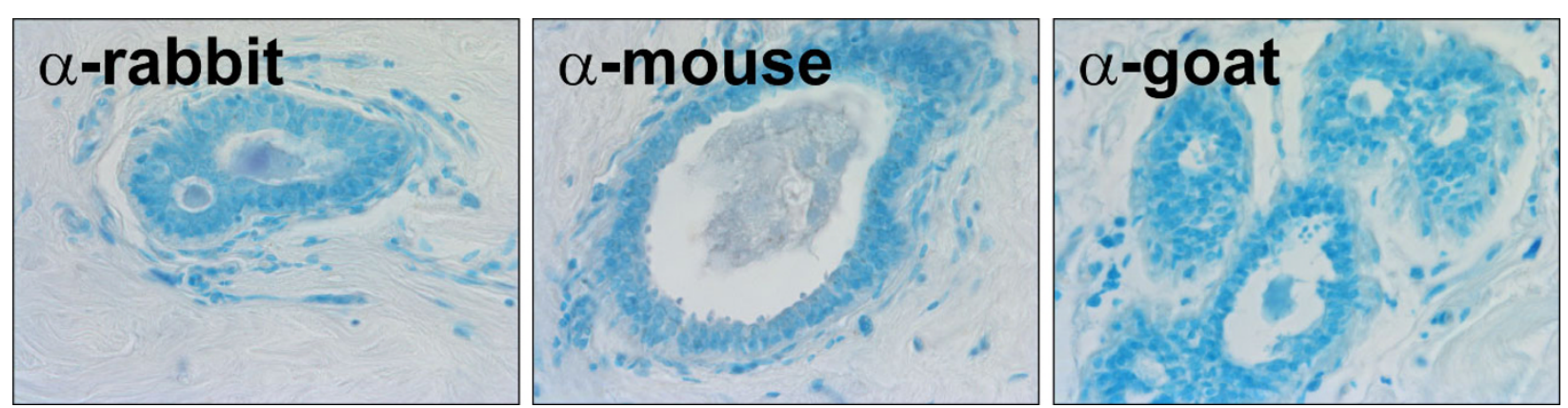

Figure 2 Validation of IHC in normal mammary tissue. Normal mammary tissue was subjected to IHC without primary antibody but with the secondary antibodies used to detect oxidative stress and DNA repair proteins as well as markers of protein and DNA damage. Representative slides are shown at 40x magnification. 


\section{SOD1}

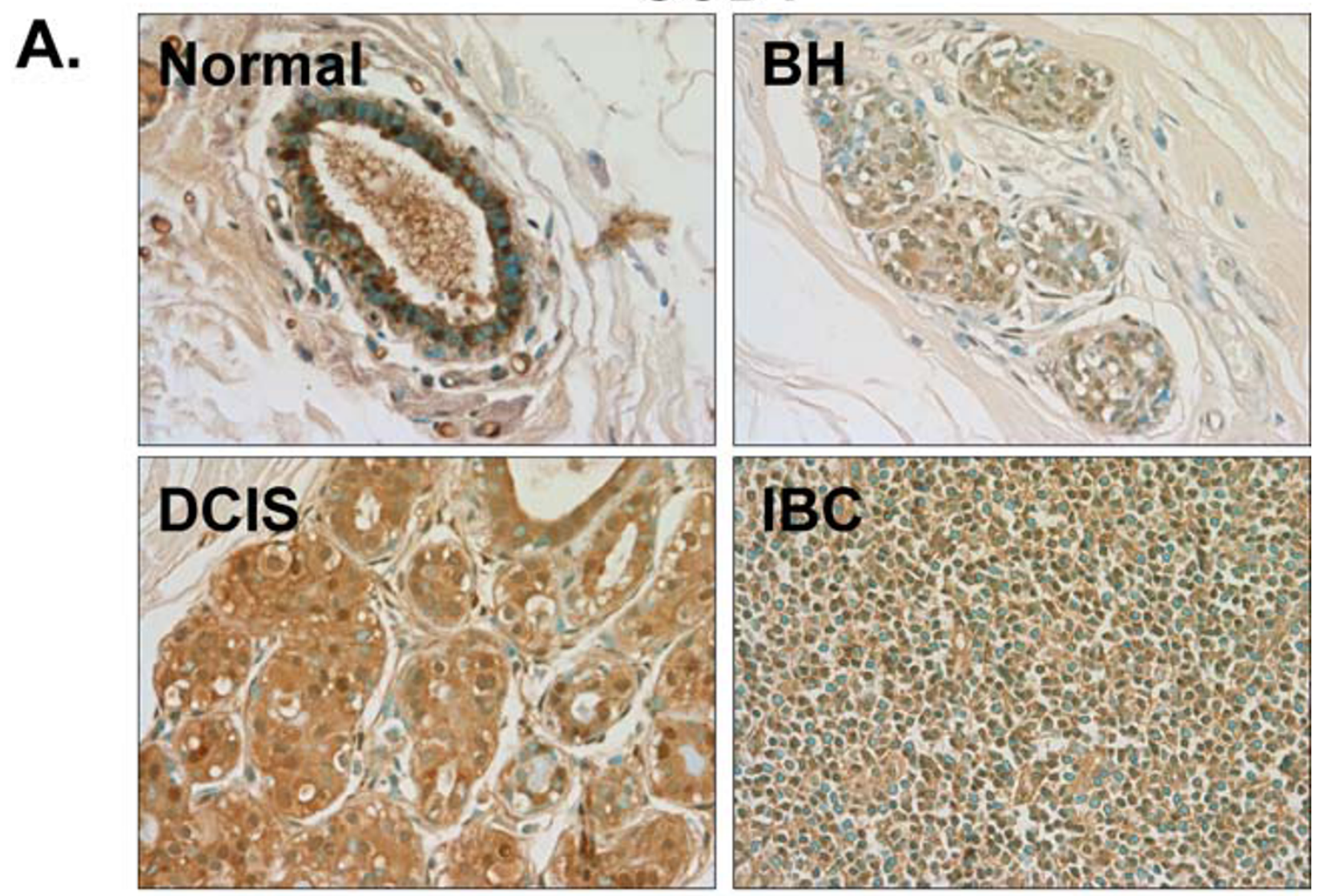

B.

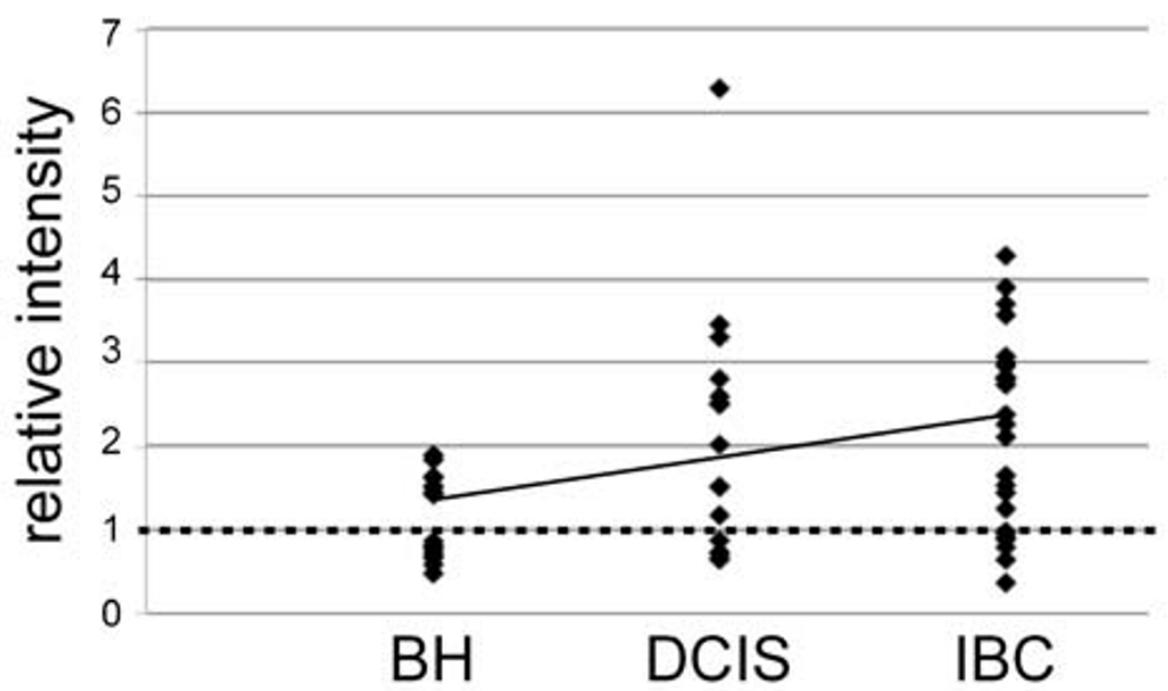

Figure 3 Expression of SOD1 in normal, BH, DCIS and IBC tissue. A. Tissues were subjected to IHC using an SOD1-specific antibody. Representative slides are shown at $40 \times$ magnification. $B$. The relative mean intensity was determined from $6-8$ images for each $B H(n=16)$, DCIS $(n=15)$ or IBC $(n=25)$ section and is shown graphically. ANOVA was used to detect statistical differences in the relative expression of BH, $\operatorname{DCIS}(p=0.0051)$ and IBC ( $p=0.0002)$ compared to normal mammary tissue, where normal mammary tissue is equal to one (dashed line). 


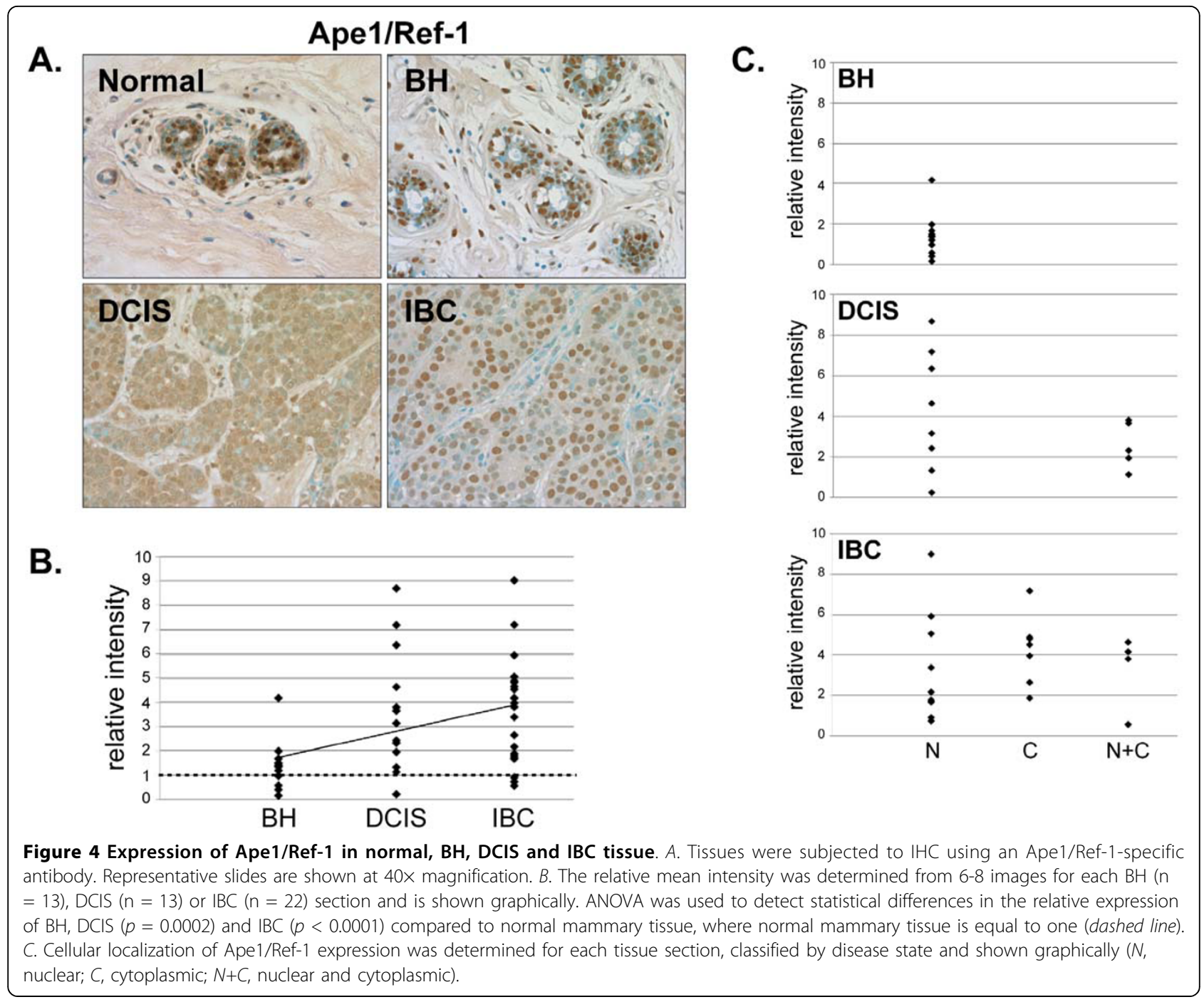

$8 \mathrm{~A}$ and $8 \mathrm{~B}$ ), the tissues with higher NM23-H1 expression had fewer positive lymph nodes (Fig. 8C). Thus, our studies are consistent with previous work, which described an inverse relationship between NM23-H1 expression and metastasis [27-30].

The base excision repair protein MPG was expressed at low levels in the stromal cells of normal mammary tissue (Fig. 9A) and was decreased in BH. MPG expression was almost completely lost in DCIS and IBC (Fig. 9A and 9B). Thus, MPG expression decreases as malignancy develops.

\section{DNA damage markers}

Antibodies directed against the DNA damage markers 8-oxoguanine (8-OxoG, Fig. 10) and $\gamma$-H2AX (Fig. 11) produced little staining and thus indicate a general lack of DNA damage in the normal mammary tissue. Although some IBC tissues had elevated levels of 8OxoG, no significant alteration in 8-OxoG staining intensity was detected in $\mathrm{BH}, \mathrm{DCIS}$ or IBC compared to normal mammary tissue (Fig. 10A and 10B). However, 8-OxoG levels were increased in ER $\alpha$-positive IBC (Fig. $10 \mathrm{C})$, indicating the presence of more abasic sites in ER $\alpha$-positive breast cancer. There was no significant change in $\gamma-\mathrm{H} 2 \mathrm{AX}$ staining in $\mathrm{BH}$, DCIS or IBC compared with normal mammary tissue (Fig. 11A and 11B).

\section{Protein damage marker}

Modest stromal staining was observed in normal mammary tissue indicating the presence of nitrotyrosine residues (Fig. 12A). While nitrotyrosine staining was increased in $82 \%(8 / 13)$ of $\mathrm{BH}$ and $69 \%$ (9/13) of DCIS tissues compared to normal breast tissue, nitrotyrosine levels were lower than normal in 77\% (20/26) of IBC tissues indicating a lack of protein damage in invasive cancer (Fig. 12A and 12B). While this at first may seem counter intuitive, increased expression of SOD1 in IBC would, in fact, decrease superoxide levels, which would in turn diminish superoxide-induced protein damage (Fig. 1 and Ref [16]). 
A.

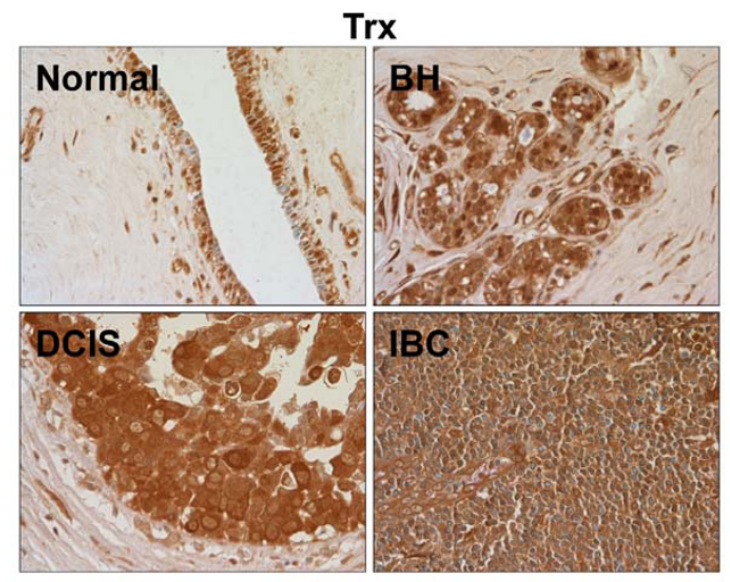

B.

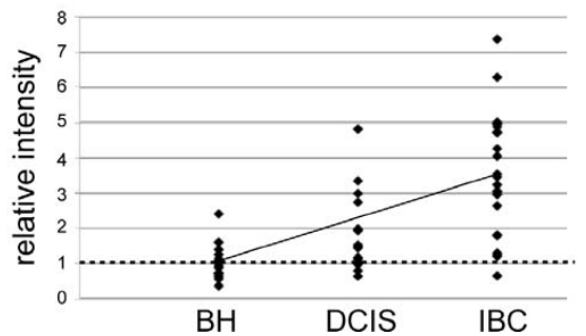

C.
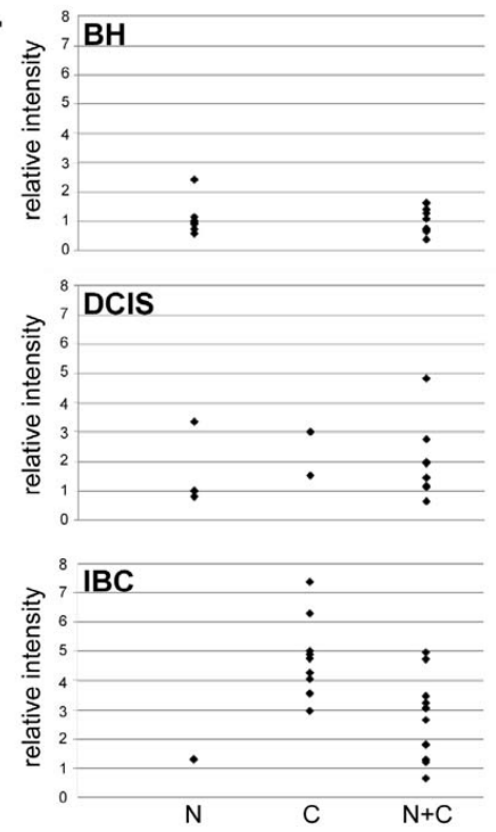

Figure 5 Expression of Trx in normal, BH, DCIS and IBC tissue. A. Tissues were subjected to IHC using a Trx-specific antibody. Representative slides are shown at 40x magnification. $B$. The relative mean intensity was determined from 6-8 images for each $B H(n=16), D C I S(n=15)$ or IBC $(n=22)$ section and is shown graphically. ANOVA was used to detect statistical differences in the relative expression of BH, DCIS $(p=0.0039)$ and IBC $(p<0.0001)$ compared to normal mammary tissue, where normal mammary tissue is equal to one (dashed line). C. Cellular localization of Trx expression was determined for each tissue section, classified by disease state and shown graphically ( $N$, nuclear; $C$, cytoplasmic; $N+C$, nuclear and cytoplasmic).

\section{Discussion}

In order to avoid ROS-induced damage to cellular macromolecules, cells rely on a diverse array of proteins to decrease oxidative stress and, if damage does occur, to repair the ROS-induced damage. Oxidative stress and DNA repair proteins promote cell survival by reducing ROS and reversing the detrimental effects of ROS accumulation. We have now shown that SOD1, Ape1/Ref-1, Trx, PDI and NM23-H1 are overexpressed and that the cellular localization of Ape1/Ref-1, Trx and PDI is altered in human breast cancer tissues.

The oxidative stress proteins SOD1, Ape1/Ref-1, Trx, TrxR, and PDI, which were first characterized in MCF-7 cells, form an interconnected network of proteins (Fig. 1 and Refs [15-18,31,32]) that help to maintain a functional intracellular environment. SOD1 converts superoxide to hydrogen peroxide and thereby plays an essential role in regulating intracellular ROS and limiting protein and DNA damage. TrxR reduces and activates Trx. In turn, Trx reduces and activates Ape1/Ref1, and together Ape1/Ref-1, Trx and TrxR help to reverse ROS-induced oxidation of numerous transcription factors and other cellular proteins $[13,14,20,33,34]$.

We previously demonstrated that increased SOD1 protects MCF-7 breast cancer cells from oxidative stress [16] and now show that SOD1 expression is increased in human breast cancer tissue. Thus, it seems plausible that the increased SOD1 expression in DCIS and IBC may help reduce ROS accumulation and promote cancer cell survival. Furthermore, the capacity of SOD1 to promote angiogenesis through activation of HIF1 $\alpha$ mediated VEGF expression [35,36] could potentially play a role in tumor progression.

Increased expression of Ape1/Ref-1, Trx and TrxR has been previously observed in human cancer [14,37-43]. Our studies provide further evidence that Ape1/Ref-1 and Trx are overexpressed in human breast cancer cells. Both proteins play critical roles in reducing and activating the transcription factors Fos, Jun, p53, HIF1 $\alpha$ and $\mathrm{NF} \kappa \mathrm{B}$, which are involved in cancer progression and promotion of cell survival $[13,14,20,33,34]$. Thus, the increased expression of Ape1/Ref-1 and Trx may 


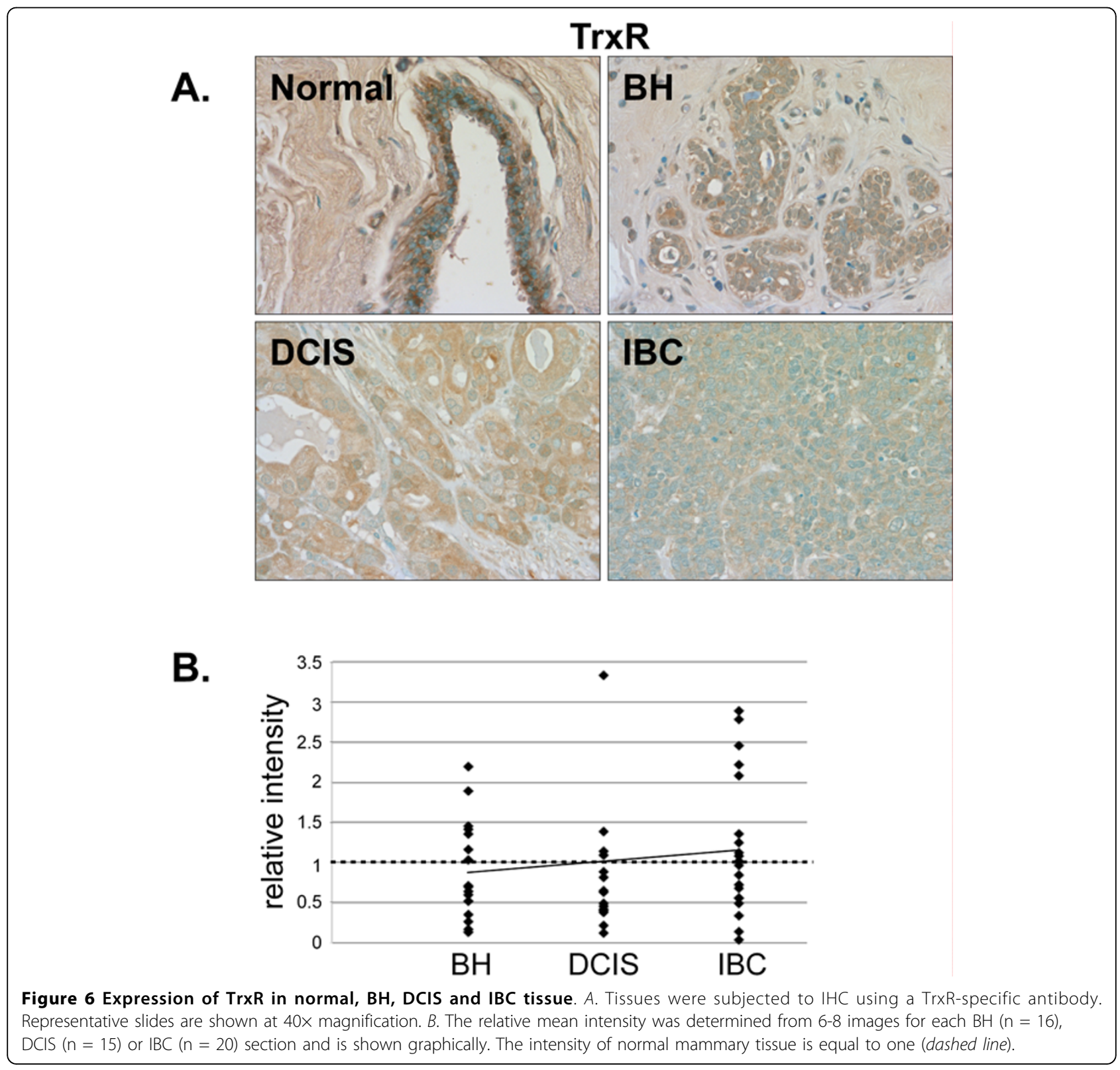

contribute to the increased proliferation and angiogenesis and decreased apoptosis that is characteristic of invasive breast cancer [19,44-50]. Further dysregulation could occur as Ape1/Ref-1 and Trx are redistributed from the nucleus to the cytoplasm in DCIS and IBC.

A previous study showed that PDI expression is increased in invasive malignant glioma and suggested that cytoplasmic PDI could promote cell adhesion and play a functional role in cell migration [51]. In fact, we observed a redistribution of PDI during oncogenesis. Although PDI was expressed in the cytoplasm and nucleus in normal mammary cells, nuclear PDI was completely lost in IBC. This redistribution from the nucleus to the cytoplasm could limit the nuclear functions of PDI and contribute to tumor invasiveness.

DNA repair proteins are required to maintain normal cell function. A loss or gain of function of any one of these proteins could feasibly result in irrevocable harm. The DNA glycosylase MPG recognizes and excises damaged bases in DNA resulting in the production of an apurinic site $[19,20,52,53]$. Overexpression of MPG causes an imbalance in DNA repair and an increase in the number of abasic sites, which can ultimately lead to double-stranded breaks and chromosomal aberrations $[21,54,55]$. Furthermore, MPG null cells have chromosomal aberrations and increased apoptosis [56]. Thus, a 


\section{A.}

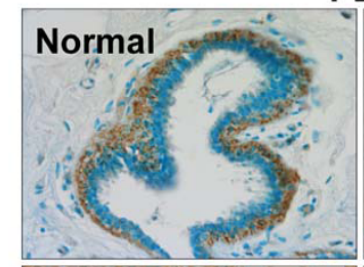

PDI

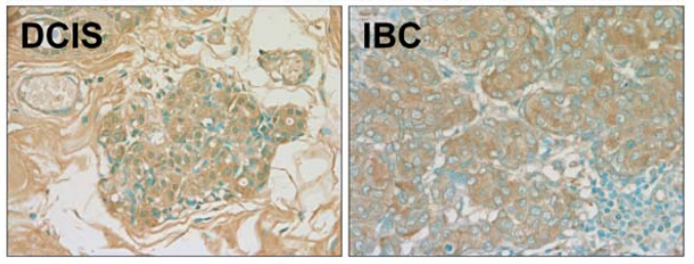

B.

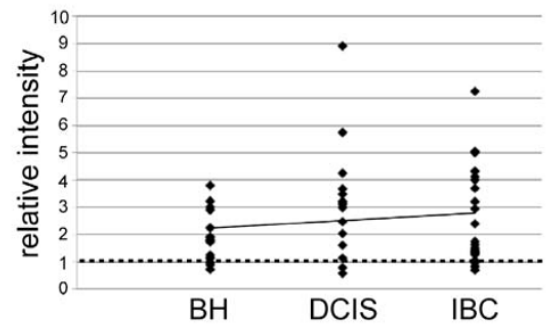

C.

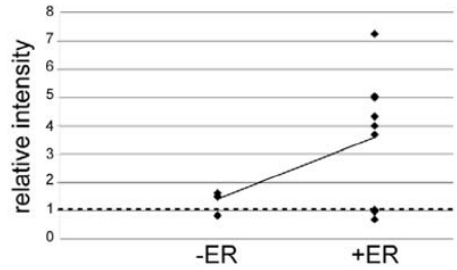

D.
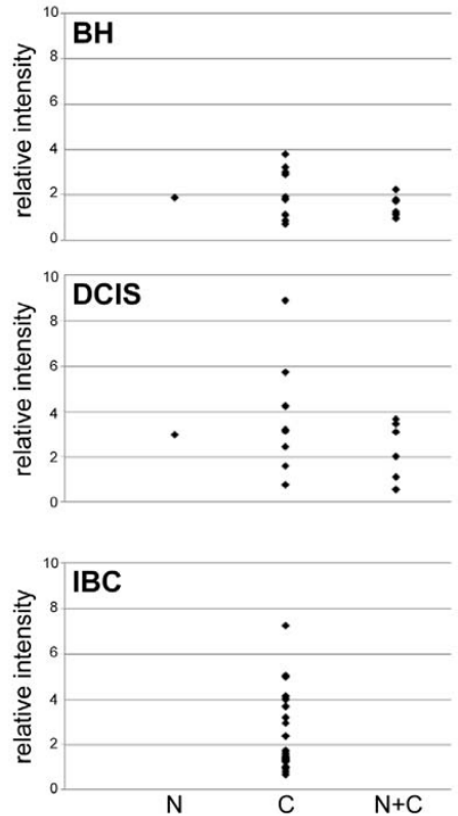

Figure 7 Expression of PDI in normal, BH, DCIS and IBC tissue. A. Tissues were subjected to IHC using a PDI-specific antibody. Representative slides are shown at 40x magnification. $B$. The relative mean intensity was determined from 6-8 images for each $B H(n=16)$, DCIS $(n=15)$ or IBC $(n=22)$ section and is shown graphically. ANOVA was used to detect statistical differences in the relative expression of BH $(p=0.0003)$, DCIS $(p=0.0002)$ and IBC $(p=0.0007)$ compared to normal mammary tissue, where normal mammary tissue is equal to one (dashed line). C. The relative mean intensity of IBC tissues was graphed according to ER $\alpha$-status. D. Cellular localization of PDI expression was determined for each tissue section, classified by disease state and shown graphically ( $N$, nuclear; $C$, cytoplasmic; $N+C$, nuclear and cytoplasmic).

decrease in MPG expression, as was observed in BH, DCIS and IBC, could cause an imbalance in DNA repair resulting in decreased DNA damage recognition and reduced DNA repair. The loss of MPG expression in breast cancer cells could potentially enhance the effectiveness of alkylating agents such as those used in chemotherapy by limiting DNA repair and enhancing apoptosis.

In addition to its role in redox regulation, Ape1/Ref-1 recognizes abasic sites produced by DNA glycosylases and nicks the DNA backbone to continue the DNA repair process $[19,20]$. Although the increased expression of Ape1/Ref- 1 would suggest that the DNA backbone would be effectively nicked at apurinic sites, the redistribution of Ape1/Ref- 1 from the nucleus to the cytoplasm would limit this process.
It has been suggested that NM23-H1 may have an intrinsic capacity to nick DNA and, in so doing, to initiate DNA repair or apoptosis (Fig. 1 and Refs $[57,58]$ ). NM23-H1 was initially characterized as a nonmetastatic factor [27,59-62]. Previous studies from our laboratory demonstrated that decreased expression of NM23-H1 in MCF-7 breast cancer cells enhances expression of Cathepsin D and $\mathrm{Bcl} 2$, which are involved in limiting apoptosis, promoting cell migration and increasing angiogenesis [26]. In contrast, overexpression of NM23H1 in a metastatic breast cancer cell line $[61,63,64]$ or injection of NM23-H1-conjugated nanoparticles into mouse xenographs results in a loss of invasiveness [65]. Likewise, as demonstrated in the current study, those breast tumors with the highest NM23-H1 expression were less likely to have migrated to the lymph nodes. 


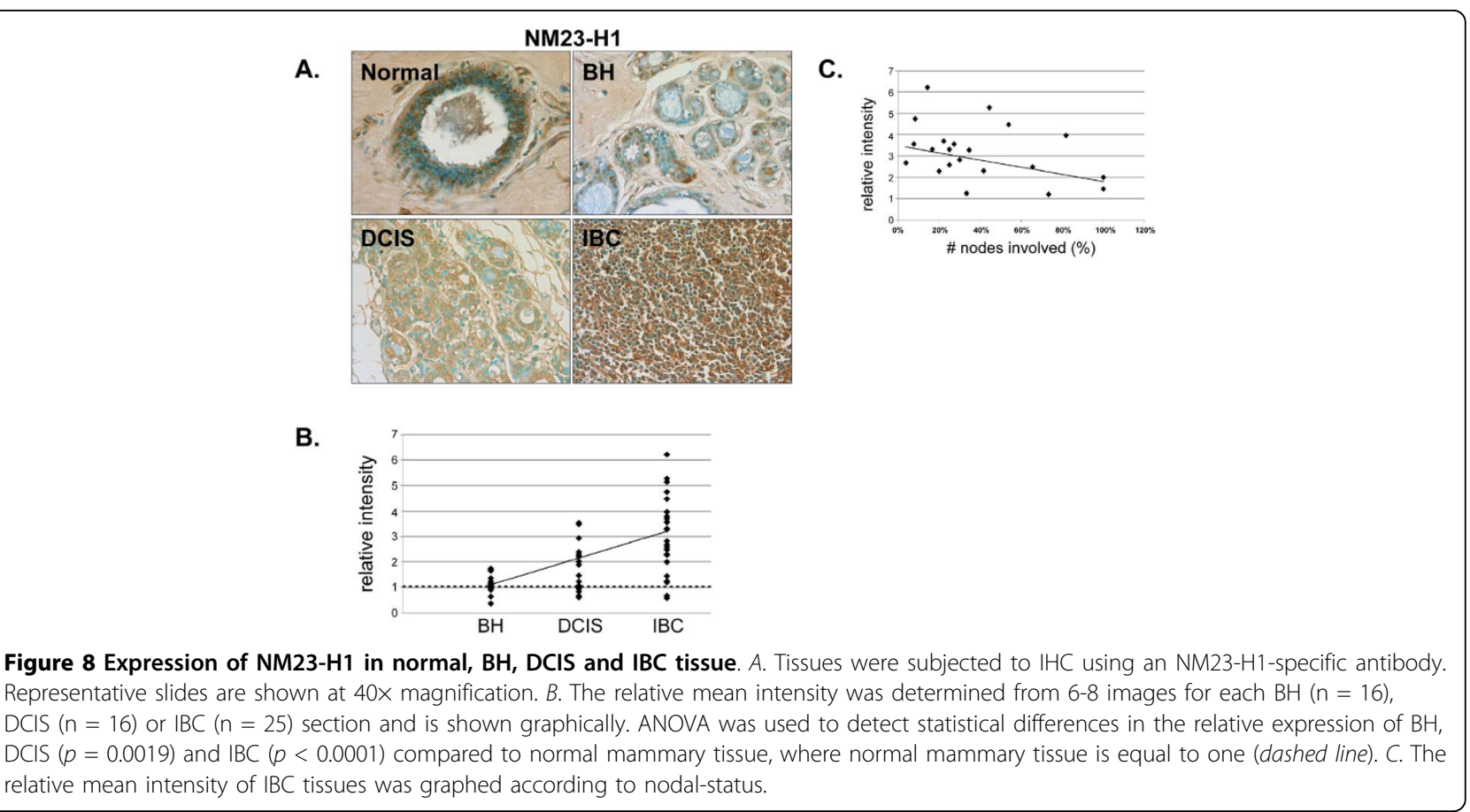

DNA lesions, such as 8-OxoG, can be induced by endogenous or exogenous alkylating agents and must be repaired in order to maintain genomic integrity. Earlier studies revealed that 8-OxoG lesions were increased in IBC compared to adjacent normal mammary tissue $[66,67]$ and that 8-OxoG lesions accumulate with age [68]. Interestingly, we observed an increase in 8-OxoG content in ER $\alpha$-positive, but not ER $\alpha$-negative IBC.

We had anticipated that DNA and/or protein damage might be increased in IBC. However, no significant increases in 8-OxoG, $\gamma$-H2AX or nitrotyrosine levels were observed in BH, DCIS or IBC compared with normal mammary tissue. It should however be noted that we were unable to detect any staining with the 8-OxoG, $\gamma$-H2AX or nitrotyrosine antibodies in normal human mammary tissue and that IBC tissues had to be utilized to define appropriate IHC conditions. Interestingly, we did detect a concomitant increase in $\gamma$-H2AX, 8-OxoG and nitrotyrosine in a subset of $\mathrm{BH}$ tissues suggesting that the limited expression of oxidative stress and DNA repair proteins in these tissues might leave them more susceptible to protein and DNA damage.

In normal cells, excess superoxide reacts with nitric oxide to produce peroxynitrite, which in turn leads to nitration of tyrosine residues (Fig. 1 and Refs[69,70]). One way that the intracellular nitrotyrosine levels may be reduced in IBC to the level found in normal mammary tissue is by the increased expression and/or activity of SOD1. In fact, increased expression of SOD1, Ape1/Ref-1 and Trx in IBC could collectively help to

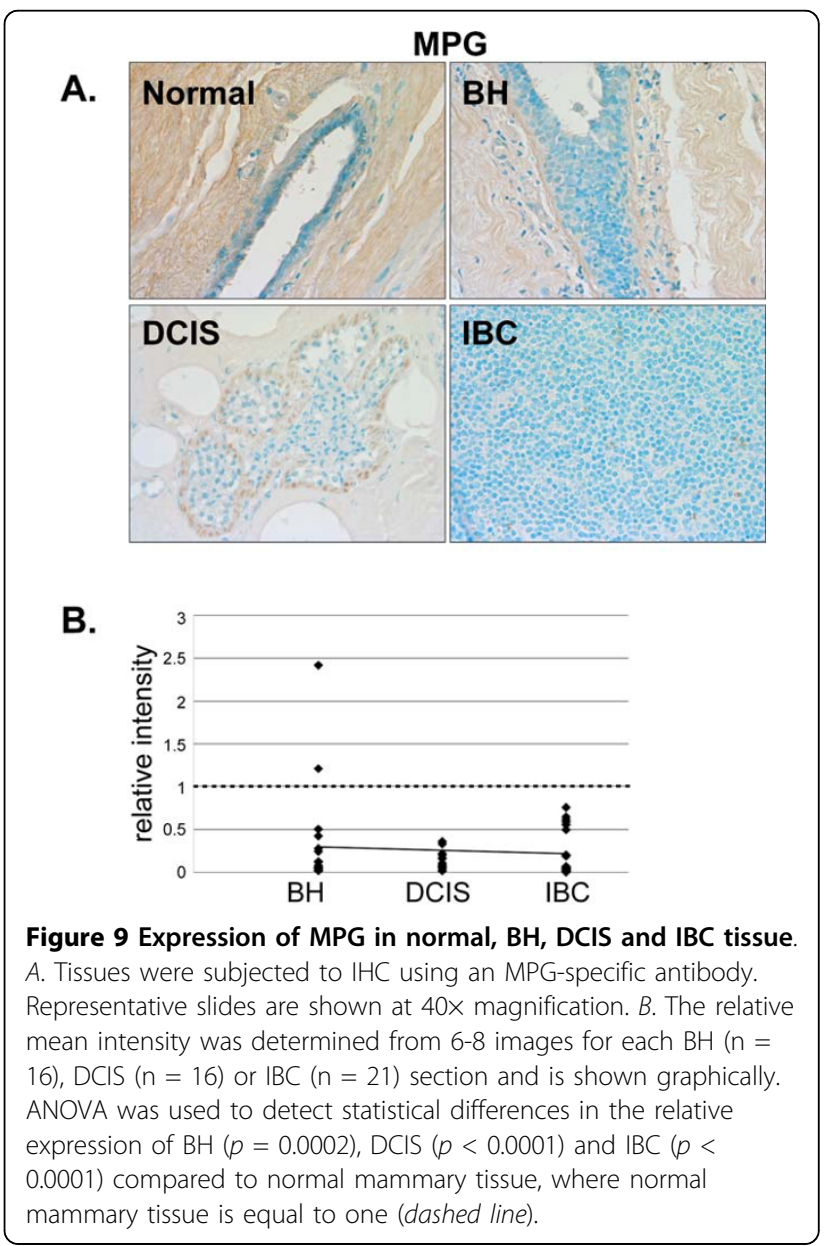




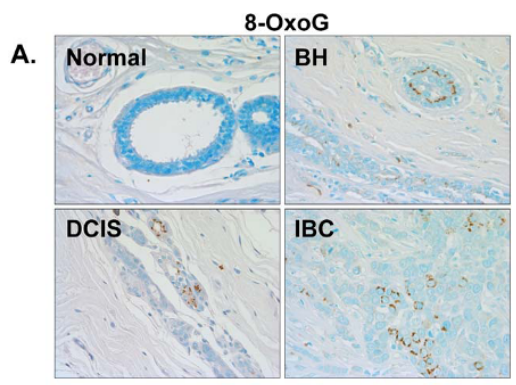

C.

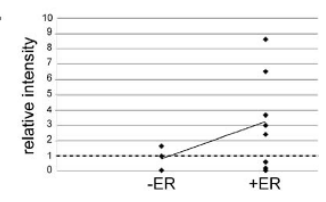

B.

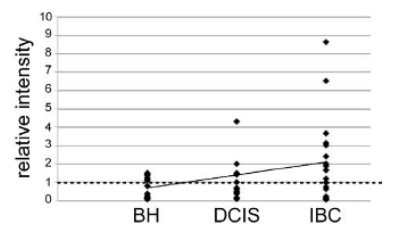

Figure 10 Analysis of the DNA lesion, 8-OxoG, in normal, BH, DCIS and IBC tissue. A. Tissues were subjected to IHC using an 8-OxoGspecific antibody. Representative slides are shown at 40x magnification. B. The relative mean intensity was determined from 6-8 images for each $\mathrm{BH}(n=15), \mathrm{DCIS}(n=15)$ or IBC $(n=19)$ section and is shown graphically. The intensity of normal mammary tissue is equal to one (dashed line). C. The relative mean intensity of IBC tissues was graphed according to ER $\alpha$-status.

dissipate ROS, maintain proper protein conformation and promote tumor cell survival.

\section{Conclusions}

We have shown that SOD1, Ape1/Ref-1, Trx, PDI and NM23-H1 are overexpressed, and that the cellular localization of Ape1/Ref-1, Trx, and PDI is altered in

A.

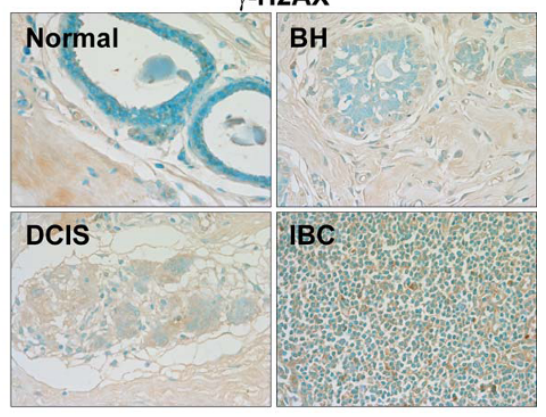

B.

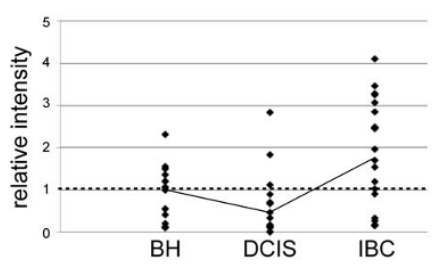

Figure 11 Expression of $\gamma-\mathrm{H} 2 \mathrm{AX}$ in normal, $\mathrm{BH}, \mathrm{DCIS}$ and IBC tissue. $A$. Tissues were subjected to $\mathrm{IHC}$ using a $\gamma$-H2AX-specific antibody. Representative slides are shown at $40 \times$ magnification. $B$. The relative mean intensity was determined from 6-8 images for each BH $(n=16), D C I S(n=16)$ or IBC $(n=22)$ section and is shown graphically. The intensity of normal mammary tissue is equal to one (dashed line). human breast cancer tissue. Our studies suggest that oxidative stress proteins (SOD1, Ape1/Ref-1, Trx, and PDI) and the DNA repair protein Ape1/Ref-1 not only protect normal cells from the damaging effects of ROS, but also promote survival of mammary tumor cells and foster tumor progression. Furthermore, overexpression of oxidative stress (SOD1, Ape1/Ref-1, Trx, and PDI) and DNA repair (MPG and Ape1/Ref-1) proteins has been shown to provide resistance to chemotherapeutic agents and impede cancer treatment [14,49,71-75]. Thus, targeting these proteins may provide an additional method of sensitizing cancer cells prior to administration of chemotherapeutic agents and aid in the development of more effective treatment regimes.

\section{Abbreviations}

ROS: reactive oxygen species; BH: benign hyperplasia; DCIS: ductal carcinoma in situ; IBC: invasive breast cancer; SOD1: Cu/Zn superoxide dismutase; Trx: thioredoxin; TrxR: thioredoxin reductase; Ape1/Ref-1: apurinic/apyrimidinic endonuclease 1/redox factor-1; PDI: protein disulfide isomerase; NM23-H1: nonmetastatic protein 23-homolog 1; MPG: 3-methyladenine DNA glycosylase; 8-OxoG: 8-oxoguanine; ERo: estrogen receptor $\alpha$.

\section{Acknowledgements}

We are indebted to Carle Foundation Hospital Surgery Center, M. Faith and the surgical team, and B. Hall for assistance in procuring the human mammary tissue. We thank G. Freund for helpful suggestions in the preparation of this manuscript. This work was supported by NIH grants R01 DK53884 and R56 DK 53884 (to AMN).

\section{Authors' contributions}

CC did all of the tissue staining, DT wrote the scripts and assisted with data analysis, and AN designed and oversaw the project and, together with CC, prepared the manuscript. All authors read and approved the final manuscript.

Received: 3 July 2009

Accepted: 11 January 2010 Published: 11 January 2010 
A.

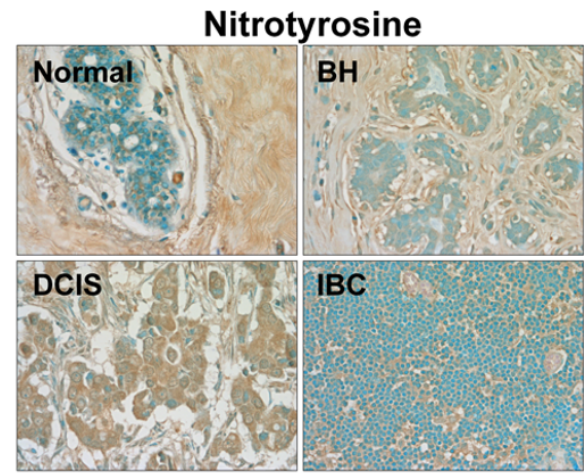

B.

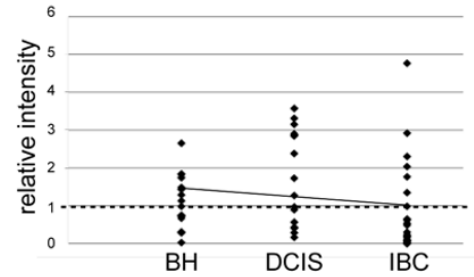

Figure 12 Expression of the protein damage marker, nitrotyrosine, in normal, BH, DCIS and IBC tissue. A. Tissues were subjected to IHC using a nitrotyrosine-specific antibody. Representative slides are shown at $40 \times$ magnification. $B$. The relative mean intensity was determined from 6-8 images for each $\mathrm{BH}(\mathrm{n}=$ $13)$, DCIS $(n=13)$ or IBC $(n=23)$ section and is shown graphically. The intensity of normal mammary tissue is equal to one (dashed line)

\section{References}

1. Wiechmann LKH: The molecular journey from ductal carcinoma in situ to invasive breast cancer. Cancer 2008, 112(10):2130-2142.

2. Jacobs TW, Connolly JL, Schnitt SJ: Nonmalignant lesions in breast core needle biopsies: to excise or not to excise?. Am J Surg Pathol 2002, 26(9):1095-1110.

3. Horak CE, Steeg PS: Metastasis gets site specific. Cancer Cell 2005, 8(2):93-95.

4. Steeg PS: Tumor metastasis: mechanistic insights and clinical challenges. Nat Med 2006, 12(8):895-904.

5. Harman D: Aging: a theory based on free radical and radiation chemistry. J Gerontol 1956, 11(3):298-300.

6. Fridovich I: Fundamental aspects of reactive oxygen species, or what's the matter with oxygen?. Ann N Y Acad Sci 1999, 893:13-18.

7. Harman D: Aging: overview. Ann N Y Acad Sci 2001, 928:1-21.

8. Muller FL, Lustgarten MS, Jang Y, Richardson A, Van Remmen H: Trends in oxidative aging theories. Free Radic Biol Med 2007, 43(4):477-503.

9. Benz CC, Yau C: Ageing, oxidative stress and cancer: paradigms in parallax. Nat Rev Cancer 2008, 8(11):875-879.

10. Zelko IN, Mariani TJ, Folz RJ: Superoxide dismutase multigene family: a comparison of the CuZn-SOD (SOD1), Mn-SOD (SOD2), and EC-SOD (SOD3) gene structures, evolution, and expression. Free Radic Biol Med 2002, 33(3):337-349.

11. Beckman JS, Koppenol WH: Nitric oxide, superoxide, and peroxynitrite: the good, the bad, and ugly. Am J Physiol 1996, 271(5 Pt 1):C1424-1437.

12. Whittal RM, Benz CC, Scott G, Semyonov J, Burlingame AL, Baldwin MA: Preferential oxidation of zinc finger 2 in estrogen receptor DNA-binding domain prevents dimerization and, hence, DNA binding. Biochemistry 2000, 39(29):8406-8417.

13. Webster KA, Prentice H, Bishopric NH: Oxidation of zinc finger transcription factors: physiological consequences. Antioxid Redox Signal 2001, 3(4):535-548

14. Evans AR, Limp-Foster M, Kelley MR: Going APE over ref-1. Mutat Res 2000, 461(2):83-108.
15. Schultz-Norton JR, McDonald WH, Yates JR, Nardulli AM: Protein disulfide isomerase serves as a molecular chaperone to maintain estrogen receptor $\alpha$ structure and function. Mol Endocrinol 2006, 20(9):1982-1995.

16. Rao AK, Ziegler YS, McLeod IX, Yates JR, Nardulli AM: Effects of Cu/Zn superoxide dismutase on estrogen responsiveness and oxidative stress in human breast cancer cells. Mol Endocrinol 2008, 22(5):1113-1124.

17. Rao AK, Ziegler YS, McLeod IX, Yates JR, Nardulli AM: Thioredoxin and thioredoxin reductase influence estrogen receptor \{alpha\} mediated gene expression in human breast cancer cells. J Mol Endocrinol 2009, 43(6):251-261.

18. Curtis CD, Thorngren DL, Ziegler YS, Sarkeshik A, Yates JR, Nardulli AM: Apurinic/apyrimidinic endonuclease 1 alters estrogen receptor activity and estrogen responsive gene expression. Mol Endocrinol 2009, 23(9):1346-1360

19. Demple B, Sung JS: Molecular and biological roles of Ape1 protein in mammalian base excision repair. DNA Repair 2005, 4(12):1442-1449.

20. Sweasy JB, Lang T, DiMaio D: Is base excision repair a tumor suppressor mechanism?. Cell Cycle 2006, 5(3):250-259.

21. Coquerelle T, Dosch J, Kaina B: Overexpression of N-methylpurine-DNA glycosylase in Chinese hamster ovary cells renders them more sensitive to the production of chromosomal aberrations by methylating agents: a case of imbalanced DNA repair. Mutat Res 1995, 336:9-17.

22. Rogakou EP, Pilch DR, Orr AH, Ivanova VS, Bonner WM: DNA doublestranded breaks induce histone H2AX phosphorylation on serine 139. Biol Chem 1998, 273(10):5858-5868.

23. Paull TT, Rogakou EP, Yamazaki V, Kirchgessner CU, Gellert M, Bonner WM: A critical role for histone $\mathrm{H} 2 \mathrm{AX}$ in recruitment of repair factors to nuclear foci after DNA damage. Curr Biol 2000, 10(15):886-895.

24. Bertram JS: The molecular biology of cancer. Mol Aspects Med 2000, 21(6):167-223.

25. Likhite VS, Cass El, Anderson SD, Yates JR, Nardulli AM: Interaction of estrogen receptor alpha with 3-methyladenine DNA glycosylase modulates transcription and DNA repair. J Biol Chem 2004, 279(16):16875-16882

26. Curtis CD, Likhite VS, McLeod IX, Yates JR, Nardulli AM: Interaction of the tumor metastasis suppressor nonmetastatic protein 23 homologue $\mathrm{H} 1$ and estrogen receptor alpha alters estrogen-responsive gene expression. Cancer Res 2007, 67(21):10600-10607.

27. Hartsough MT, Steeg PS: Nm23/nucleoside diphosphate kinase in human cancers. J Bioenerg Biomembr 2000, 32(3):301-308.

28. Bertheau P, Steinberg SM, Merino MJ: C-erbB-2, p53, and nm23 gene product expression in breast cancer in young women immunohistochemical analysis and clinicopathologic correlation. Hum Pathol 1998, 29(4):323-329.

29. Duenas-Gonzalez A, Abad-Hernandez MM, Garcia-Mata J, Paz-Bouza J, CruzHernandez JJ, Gonzalez-Sarmiento R: Analysis of nm23-H1 expression in breast cancer. Correlation with p53 expression and clinicopathologic findings. Cancer Lett 1996, 101(2):137-142.

30. Yoshida H, Kijima H, Terasaki Y, Suto A, Takeshita T, Omiya H, Shimojima K, Shimbori M, Sato T, Sato S, et al: Heterogeneous expression of nm23 gene product as a predictor of lymph nodal status in human breast cancer. Int J Oncol 1998, 13(6):1141-1146.

31. Schultz-Norton JR, Ziegler YS, Likhite VS, Nardulli AM: Isolation of proteins associated with the DNA-bound estrogen receptor $\alpha$. Molecular Endocrinology: A Comprehensive Guide to Current Methodologies Totowa, NJ: Humana Press, USAPark Sarge O-K, Curry T 2009, 590:209-221.

32. Schultz-Norton JR, Ziegler YS, Likhite VS, Yates JR, Nardulli AM: Isolation of novel coregulatory protein networks associated with DNA-bound estrogen receptor alpha. BMC Mol Biol 2008, 9:97.

33. Hirota K, Matsui M, Iwata S, Nishiyama A, Mori K, Yodoi J: AP-1 transcriptional activity is regulated by a direct association between thioredoxin and Ref-1. Proc Natl Acad Sci USA 1997, 94(8):3633-3638.

34. Jayaraman L, Murthy KG, Zhu C, Curran T, Xanthoudakis S, Prives C: Identification of redox/repair protein Ref-1 as a potent activator of p53. Genes Dev 1997, 11(5):558-570.

35. Grzenkowicz-Wydra J, Cisowski J, Nakonieczna J, Zarebski A, Udilova N, Nohl H, Jozkowicz A, Podhajska A, Dulak J: Gene transfer of CuZn superoxide dismutase enhances the synthesis of vascular endothelial growth factor. Mol Cell Biochem 2004, 264(1-2):169-181.

36. Juarez JC, Betancourt O Jr, Pirie-Shepherd SR, Guan X, Price ML, Shaw DE, Mazar AP, Donate F: Copper binding by tetrathiomolybdate attenuates 
angiogenesis and tumor cell proliferation through the inhibition of superoxide dismutase 1. Clin Cancer Res 2006, 12(16):4974-4982.

37. Mustacich D, Powis G: Thioredoxin reductase. Biochem J 2000, 346(Pt 1):1-8.

38. Bobola MS, Blank A, Berger MS, Stevens BA, Silber JR: Apurinic/apyrimidinic endonuclease activity is elevated in human adult gliomas. Clin Cancer Res 2001, 7(11):3510-3518.

39. Kelley MR, Cheng L, Foster R, Tritt R, Jiang J, Broshears J, Koch M: Elevated and altered expression of the multifunctional DNA base excision repair and redox enzyme Ape1/ref-1 in prostate cancer. Clin Cancer Res 2001 7(4):824-830.

40. Robertson KA, Bullock HA, Xu Y, Tritt R, Zimmerman E, Ulbright TM, Foster RS, Einhorn LH, Kelley MR: Altered expression of Ape1/ref-1 in germ cell tumors and overexpression in NT2 cells confers resistance to bleomycin and radiation. Cancer Res 2001, 61(5):2220-2225.

41. Han H, Bearss DJ, Browne LW, Calaluce R, Nagle RB, Von Hoff DD: Identification of differentially expressed genes in pancreatic cancer cells using cDNA microarray. Cancer Res 2002, 62(10):2890-2896.

42. Lincoln DT, Ali Emadi EM, Tonissen KF, Clarke FM: The thioredoxinthioredoxin reductase system: over-expression in human cancer. Anticancer Res 2003, 23(3B):2425-2433.

43. Turunen N, Karihtala P, Mantyniemi A, Sormunen R, Holmgren A, Kinnula $\mathrm{VL}$, Soini $Y$ : Thioredoxin is associated with proliferation, p53 expression and negative estrogen and progesterone receptor status in breast carcinoma. Apmis 2004, 112(2):123-132.

44. Powis $G$, Mustacich $D$, Coon A: The role of the redox protein thioredoxin in cell growth and cancer. Free Radic Biol Med 2000, 29(3-4):312-322.

45. Welsh SJ, Bellamy WT, Briehl MM, Powis G: The redox protein thioredoxin$1(\operatorname{Trx}-1)$ increases hypoxia-inducible factor $1 \alpha$ protein expression: Trx-1 overexpression results in increased vascular endothelial growth factor production and enhanced tumor angiogenesis. Cancer Res 2002, 62(17):5089-5095.

46. Smart DK, Ortiz KL, Mattson D, Bradbury CM, Bisht KS, Sieck LK, Brechbiel MW, Gius D: Thioredoxin reductase as a potential molecular target for anticancer agents that induce oxidative stress. Cancer Res 2004 64(18):6716-6724.

47. Burke-Gaffney A, Callister ME, Nakamura H: Thioredoxin: friend or foe in human disease?. Trends Pharmacol Sci 2005, 26(8):398-404.

48. Zou GM, Luo MH, Reed A, Kelley MR, Yoder MC: Ape1 regulates hematopoietic differentiation of embryonic stem cells through its redox functional domain. Blood 2007, 109(5):1917-1922.

49. Fishel ML, Kelley MR: The DNA base excision repair protein Ape1/Ref-1 as a therapeutic and chemopreventive target. Mol Aspects Med 2007, 28(34):375-395

50. Mukherjee A, Martin SG: The thioredoxin system: a key target in tumour and endothelial cells. Br J Radiol 2008, 81(Spec No 1):S57-68

51. Goplen D, Wang J, Enger PO, Tysnes BB, Terzis AJ, Laerum OD, Bjerkvig R: Protein disulfide isomerase expression is related to the invasive properties of malignant glioma. Cancer Res 2006, 66(20):9895-9902.

52. Hansen WK, Kelley MR: Review of mammalian DNA repair and translational implications. J Pharmacol Exp Ther 2000, 295(1):1-9.

53. Scharer OD, Jiricny J: Recent progress in the biology, chemistry and structural biology of DNA glycosylases. Bioessays 2001, 23:270-281.

54. Fishel ML, Seo YR, Smith ML, Kelley MR: Imbalancing the DNA base excision repair pathway in the mitochondria; targeting and overexpressing $\mathrm{N}$-methylpurine DNA glycosylase in mitochondria leads to enhanced cell killing. Cancer Res 2003, 63(3):608-615.

55. Rinne M, Caldwell D, Kelley MR: Transient adenoviral N-methylpurine DNA glycosylase overexpression imparts chemotherapeutic sensitivity to human breast cancer cells. Mol Cancer Ther 2004, 3(8):955-967.

56. Engelward BP, Allan JM, Dreslin AJ, Kelly JD, Wu MM, Gold B, Samson LD: A chemical and genetic approach together define the biological consequences of 3-methyladenine lesions in the mammalian genome. $J$ Biol Chem 1998, 273:5412-5418.

57. Fan Z, Beresford PJ, Oh DY, Zhang D, Lieberman J: Tumor suppressor NM23-H1 is a granzyme A-activated DNase during CTL-mediated apoptosis, and the nucleosome assembly protein SET is its inhibitor. Cell 2003, 112(5):659-672.

58. Chowdhury D, Beresford PJ, Zhu P, Zhang D, Sung JS, Demple B, Perrino FW, Lieberman J: The exonuclease TREX1 is in the SET complex and acts in concert with NM23-H1 to degrade DNA during granzyme Amediated cell death. Mol Cell 2006, 23(1):133-142.
59. Steeg PS: Search for metastasis suppressor genes. Invasion Metastasis 1989, 9(6):351-359.

60. Steeg PS, Palmieri D, Ouatas T, Salerno M: Histidine kinases and histidine phosphorylated proteins in mammalian cell biology, signal transduction and cancer. Cancer Lett 2003, 190(1):1-12.

61. Steeg PS, Ouatas T, Halverson D, Palmieri D, Salerno M: Metastasis suppressor genes: basic biology and potential clinical use. Clin Breast Cancer 2003, 4(1):51-62.

62. Heimann R, Ferguson DJ, Hellman S: The relationship between $n m 23$, angiogenesis, and the metastatic proclivity of node-negative breast cancer. Cancer Res 1998, 58(13):2766-2771.

63. Leone A, Flatow U, VanHoutte K, Steeg PS: Transfection of human nm23$\mathrm{H} 1$ into the human MDA-MB-435 breast carcinoma cell line: effects on tumor metastatic potential, colonization and enzymatic activity. Oncogene 1993, 8(9):2325-2333.

64. Russell RL, Pedersen AN, Kantor J, Geisinger K, Long R, Zbieranski N, Townsend A, Shelton B, Brunner N, Kute TE: Relationship of nm23 to proteolytic factors, proliferation and motility in breast cancer tissues and cell lines. Br J Cancer 1998, 78(6):710-717.

65. Li Z, Xiang J, Zhang W, Fan S, Wu M, Li X, Li G: Nanoparticle delivery of anti-metastatic NM23-H1 gene improves chemotherapy in a mouse tumor model. Cancer Gene Ther 2009, 16(5):423-429.

66. Malins DC, Haimanot R: Major alterations in the nucleotide structure of DNA in cancer of the female breast. Cancer Res 1991, 51(19):5430-5432.

67. Toyokuni S, Okamoto K, Yodoi J, Hiai H: Persistent oxidative stress in cancer. FEBS Lett 1995, 358(1):1-3.

68. Malins DC, Anderson KM, Jaruga P, Ramsey CR, Gilman NK, Green VM, Rostad SW, Emerman JT, Dizdaroglu M: Oxidative changes in the DNA of stroma and epithelium from the female breast: potential implications for breast cancer. Cell Cycle 2006, 5(15):1629-1632

69. Beckman JS, Carson M, Smith CD, Koppenol WH: ALS, SOD and peroxynitrite. Nature 1993, 364(6438):584

70. Squadrito GL, Pryor WA: Oxidative chemistry of nitric oxide: the roles of superoxide, peroxynitrite, and carbon dioxide. Free Radic Biol Med 1998, 25(4-5):392-403.

71. Bianchi MS, Bianchi NO, Bolzan AD: Superoxide dismutase activity and superoxide dismutase-1 gene methylation in normal and tumoral human breast tissues. Cancer Genet Cytogenet 1992, 59(1):26-29.

72. Starcevic SL, Diotte NM, Zukowski KL, Cameron MJ, Novak RF: Oxidative DNA damage and repair in a cell lineage model of human proliferative breast disease (PBD). Toxicol Sci 2003, 75(1):74-81.

73. Wang D, Luo M, Kelley MR: Human apurinic endonuclease 1 (APE1) expression and prognostic significance in osteosarcoma: enhanced sensitivity of osteosarcoma to DNA damaging agents using silencing RNA APE1 expression inhibition. Mol Cancer Ther 2004, 3(6):679-686.

74. MCNeill DR, Wilson DM: A dominant-negative form of the major human abasic endonuclease enhances cellular sensitivity to laboratory and clinical DNA-damaging agents. Mol Cancer Res 2007, 5(1):61-70.

75. Brown DP, Chin-Sinex H, Nie B, Mendonca MS, Wang M: Targeting superoxide dismutase 1 to overcome cisplatin resistance in human ovarian cancer. Cancer Chemother Pharmacol 2009, 63(4):723-730.

\section{Pre-publication history}

The pre-publication history for this paper can be accessed here:http://www. biomedcentral.com/1471-2407/10/9/prepub

doi:10.1186/1471-2407-10-9

Cite this article as: Curtis et al:: Immunohistochemical analysis of oxidative stress and DNA repair proteins in normal mammary and breast cancer tissues. BMC Cancer 2010 10:9. 